\title{
Interaction Between the Cannabinoid and Vanilloid Systems on Anxiety in Male Rats
}

\author{
Nafiseh Faraji ${ }^{1,2}$, Alireza Komaki ${ }^{1 *}$, Iraj Salehi ${ }^{1}$ \\ 1. Neurophysiology Research Center, Hamadan University of Medical Sciences, Hamadan, Iran. \\ 2. Department of Biology, Hamadan Branch, Islamic Azad University, Hamadan, Iran.
}

Citation: Faraji, N., Komaki, A., Salehi, I. (2017). Interaction Between the Cannabinoid and Vanilloid Systems on Anxiety in Male Rats. Basic and Clinical Neuroscience, 8(2), 129-138. https://doi.org/10.18869/nirp.bcn.8.2.129

https://doi.org/10.18869/nirp.ben.8.2.129

Article info:

Received: 09 August 2016 First Revision: 18 August 2016 Accepted: 07 December 2016
Key Words:

Anxiety, Elevated plus maze, $\mathrm{CB} 1$ receptors, TRPV1 receptors, Rat

\begin{abstract}
A B S T RA C T
Introduction: Previous studies have shown that the cannabinoid system is involved in anxiety. In addition, transient receptor potential vanilloid type-1 (TRPV1) channels are new targets for the development of anxiolytics. The present study investigated the possible interaction between the cannabinoid and vanilloid systems on anxiety-like behavior in rats.

Methods: Four different groups of male Wistar rats received intraperitoneal (IP) injections of (1) vehicle (DMSO+saline), (2) cannabinoid receptor agonist WIN55212-2 (WIN) (1 mg/kg), (3) TRPV1 receptor antagonist capsazepine (CPZ) $(5 \mathrm{mg} / \mathrm{kg})$, or (4) combined WIN $(1 \mathrm{mg} / \mathrm{kg})$ and CPZ $(5 \mathrm{mg} / \mathrm{kg})$ treatment 30 minutes before testing in the elevated plus maze.

Results: The results showed that compared to the control (vehicle), both WIN and CPZ increased the time spent and number of entries on the open arms. Co-administration of WIN and CPZ had a synergistic effect, i.e., the number of entries and time spent on the open arms was greater than that in the groups administered the two compounds alone. The total distance travelled by rats and total number of entries on to the arms did not significantly differ between groups.

Conclusion: Acute neuropharmacological blockade of the TRPV1 receptor or stimulation of the CB1 receptor produced an anxiolytic effect. It seems that antagonism of the vanilloid system modulates cannabinoid gain that rises the anxiolytic effect. TRPV1 antagonism may amend generation of endocannabinoids, which in turn increases anxiolytic impact. These results suggest that two systems could act on or share a common signaling pathway affecting the expression of anxiety.
\end{abstract}

\section{Introduction}

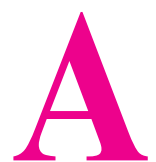

nxiety disorders are the most common mental disorders in modern society (Di Marzo et al., 1998; Schneier, 2011). Many neurotransmitters such as the GABAergic, noradrenergic, and endocannabinoid sys- tems modulate anxiety (Viveros, Marco, \& File, 2005) through their actions in various brain regions (Herkenham et al., 1990). There is accumulating evidence that Cannabis sativa, acting via the cannabinoid system, modulates the expression of anxiety (Bergamaschi, Queiroz, Zuardi, \& Crippa, 2011; Crippa et al., 2011; Hill and Gorzalka, 2004; Schneier, 2011). There have

* Corresponding Author:

Alireza Komaki, PhD

Address: Neurophysiology Research Center, Hamadan University of Medical Sciences, Shahid Fahmideh St., Hamadan, Iran

Tel: +98 (81) 38380267

E-mail: alirezakomaki@gmail.com 
been numerous studies on the effects of the cannabinoid system in modulating anxiety but with conflicting results (Haller, Bakos, Szirmay, Ledent, \& Freund, 2002; Marco and Viveros, 2008; Navarro et al., 1997; Patel and Hillard, 2006; Viveros, Marco, \& File, 2005; Komaki, Abdollahzadeh, Sarihi, Shahidi, \& Salehi, 2014a; Komaki et al. 2015a).

The endogenous cannabinoid system, also known as the endocannabinoid system, regulates the expression of anxiety (Ruehle, Rey, Remmers, \& Lutz, 2012). Cannabinoid receptor agents have been shown to exert anxiolytic (Patel and Hillard, 2006; Saito, Wotjak, \& Moreira, 2010) and anxiogenic effects (Carvalho and Van Bockstaele, 2012; Degroot, 2008, Haller et al., 2004a; Haller et al., 2004b; Moreira, Aguiar, \& Guimarães, 2007; Moreira, Kaiser, Monory, \& Lutz, 2008). Cannabinoid agents act through two receptors: CB1 and CB2 (Howlett et al., 2002). CB1 is the most abundant G-protein coupled receptor found in the mammalian brain (Matsuda, Lolait, Brownstein, Young, \& Bonner, 1990) and are particularly abundant in the cortex, hippocampus, nucleus accumbens, and amygdala (Millan, 2003). The blockade and genetic deletion of the CB1 cannabinoid receptor modulate anxiety in mice (Haller, et al., 2002; Thiemann, Watt, Ledent, Molleman, \& Hasenöhrl, 2009).

Transient receptor potential vanilloid-1 (TRPV1) receptor is a subfamily of vanilloid family (Morales-Lazaro Simon, \& Rosenbaum, 2013). TRPV1 is expressed widely throughout the central nervous system and peripheral afferent fibers (Caterina, Schumacher, Tominaga, Rosen, \& Levine, 1997; Chung, Lee, Yuichi, \& Willis, 1985; Roberts, Davis, \& Benham, 2004; Tóth, Blumberg, \& Boczán, 2005). TRPV1 promotes neuronal depolarization, increasing their firing rate and synaptic activity (Xing and Li, 2007). It has been shown that TRPV1 also modulates anxiety behavior (Kasckow, Mulchahey, \& Thomas, 2004; Marsch et al., 2007). Similar to the reports of cannabinoid modulation of anxiety, the effects of the vanilloid system on the expression of anxiety are controversial (Aguiar, Terzian, Guimarães, \& Moreira, 2009; Mascarenhas, Gomes, \& Nunes-de-Souza, 2013).

Previous studies reported that the co-expression of CB1 and TRPV1 receptors was observed in several brain regions (Cristino et al., 2006; Mezey, 2000; Sagar et al., 2004; Tóth, Blumberg, \& Boczán, 2005). There are functional relationships between $\mathrm{CB} 1$ and TRPV1 receptors in the nervous system (Hermann et al., 2003; Kim, Bok, Chung, Chung, \& Jin, 2009; Sagar et al., 2004). Further, the cannabinoid and vanilloid systems interact in the brain to modulate anxiogenic behavior (Aguiar et al., 2009;
Fogaça, Aguiar, Moreira, \& Guimarães, 2012; Moreira, Aguiar, \& Guimarães, 2007; Rubino et al., 2007).

While data is available on the individual effects of the cannabinoid and vanilloid systems in the expression of anxiety, the simultaneous stimulation or inactivation of these two systems and their interactive mechanisms have not been studied for their effects on the expression of anxiety. Thus in this experiment, we intend to evaluate the hypothesis that the effects of the cannabinoid system on anxiety are mediated by the vanilloid system results, specifically through the activity of TRPV1 receptors. The interaction of these two neuromodulators in the modification of anxiety could have remedial significance in clinical situation. In the present experiment, we examined the consequences of co-administration of a cannabinoid agonist and a vanilloid antagonist on the expression of anxiety-like behaviors in rats.

\section{Methods}

\subsection{Animals}

Male Wistar rats (obtained from the Razi institute, Iran) weighing 200-250 g were used throughout these experiments. Animals were housed in groups of four per cage under a $12 \mathrm{~h}$ light/dark cycle (lights on at $07: 00 \mathrm{~h}$ ) at a constant temperature of $23 \pm 2{ }^{\circ} \mathrm{C}$ and given ad libitum food and water. All experiments were carried out in a quiet room under controlled light conditions between 11:00 and 15:00. Animals were allowed to acclimate to vivarium conditions for 1 week prior to behavioral testing. The experimental protocols were approved by the Hamadan University of Medical Sciences and were conducted in accordance with the Guide for Care and Use of Laboratory Animals published by the United States National Institutes of Health (NIH Publication No. 85-23, revised 1985).

\subsection{Drugs and administration}

WIN 212-2 [(R)-(+)-[2,3-Dihydro-5-methyl-3-(4morpholinylmethyl) pyrrolo [1,2,3-de]-1, 4-benzoxazin-6-yl]-1-napthalenylmethanone] (WIN) (Sigma-Aldrich,Germany) and capsazepine [N-[2-(4Chlorophenyl)ethyl]-1,3,4,5-tetrahydro-7,8-dihydroxy-2H-2-benzazepine-2-carbothioamide] (CPZ) (Tocris, UK) were dissolved in dimethyl sulfoxide (DMSO; Sigma-Aldrich, Germany) + saline. The solutions were prepared freshly. The animals were randomly divided into the control group and 3 experimental groups. The control group $(\mathrm{n}=10)$ received vehicle (saline+DMSO 8\%). All rats received intraperitoneal 
(IP) injections in a volume of $1 \mathrm{~mL} / \mathrm{kg} 30$ minutes prior to behavioral testing. One week after acclimatization, CPZ $(n=10)$, WIN ( $n=10)$, or a combination of these drugs $(\mathrm{WIN}+\mathrm{CPZ})(\mathrm{n}=10)$ were administered 30 minutes prior to behavioral testing. Drug doses were calculated based on preceding experiments: WIN: 1 mg/kg; IP (Richter and Löscher, 1994; Baek, et al., 2009; Burgos, et al., 2010; Fernández-López, et al., 2010; Shabani, et al., 2012; Komaki, et al., 2015a) and CPZ: $5 \mathrm{mg} / \mathrm{kg}$; IP (Cabranes, et al., 2005; Nguyen, et al., 2010; Almeida, et al., 2014; Kaczocha, et al., 2015; Magierowski, et al., 2015).

\subsection{Elevated Plus-Maze (EPM)}

The apparatus consisted of two opposing open arms $(50 \times 10 \mathrm{~cm}$ each) without side walls, adjacent to two enclosed arms $(50 \times 10 \times 50 \mathrm{~cm}$ each $)$, with a central platform common to all arms $(10 \times 10 \mathrm{~cm})$. The apparatus was elevated $50 \mathrm{~cm}$ above the ground (Pellow et al., 1985; Pellow and File, 1986). Thirty minutes after drug administration, each animal was placed in the center of the maze, facing one of the open arms. The rats were allowed to explore the maze, and their behavior was recorded for 10 minutes by using a digital camera mounted above the maze. The time spent and percentage of entries on to the open and enclosed arms were recorded. Distance travelled was calculated and used as a measure of locomotion during the 10 minutes test period (Lister, 1987; Ganji et al., 2016). After each test, the apparatus was cleaned with $10 \%$ ethanol to eliminate the remaining odors. Each animal was used only once.

\subsection{Statistical analysis}

The statistical analysis of data was performed by one-way analysis of variance (ANOVA) followed by Tukey post-hoc analysis. All the results are presented in terms of mean \pm SEM. A p value less than 0.05 was considered to be significant.

\section{Results}

\subsection{Effects on the total distance covered by rats}

The total distance covered by the WIN, CPZ, and $\mathrm{WIN}+\mathrm{CPZ}$ treated rats during the 10 minutes test period was not significantly different from controls (Figure 1).

3.2. Effects on the percentage of entries on to the open arms

The effects of WIN, CPZ, and WIN+CPZ on the percentage of entries on to the open arms are shown in Figure 2. One-way ANOVA revealed a significant difference between experimental groups in percentage of entries on to the open arms. Tukey's post-hoc tests revealed significant increases in percentage of entries on to the open arms after administration of WIN, CPZ $(\mathrm{P}<0.05)$, and after the co-administration of WIN and $\mathrm{CPZ}(\mathrm{P}<0.01)$ in comparison with the control group. Percentage of entries on to the open arms after co-administration of WIN and CPZ was significantly higher than the WIN and CPZ treated groups $(\mathrm{P}<0.05)$.

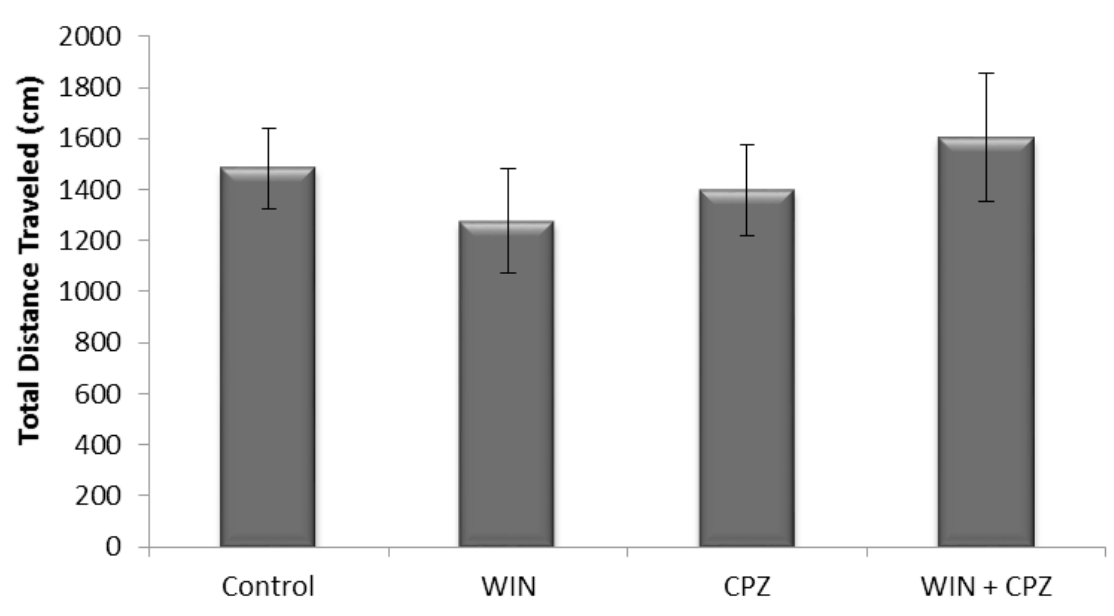

NEUR:SCIENCE

Figure 1. The effect of WIN212-2 (WIN), capsazepine (CPZ) and co-administration WIN+CPZ on the total distance covered by the rats during the $10 \mathrm{~min}$ test session ( $\mathrm{n}=10$ in each group). Data are presented as mean \pm SEM. 


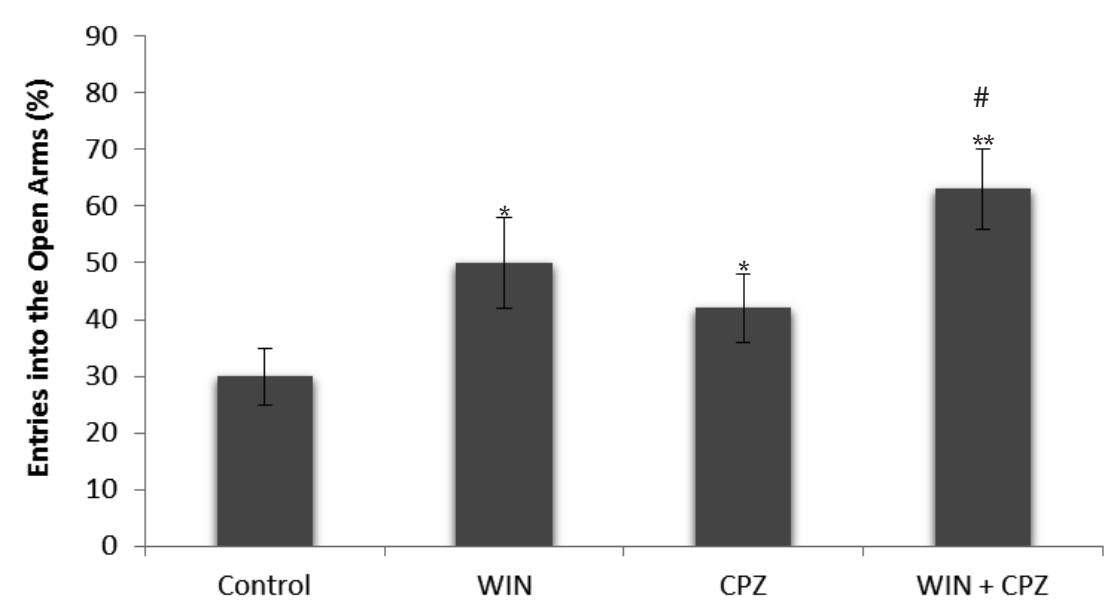

NEUR:SCIENCE

Figure 2. The effect of WIN212-2 (WIN), capsazepine (CPZ) and co-administration WIN+CPZ on the percentage of entries on to the open arms during the 10-min test session ( $n=10$ in each group). Data are presented as mean $\pm S E M$.

*: $\mathrm{P}<0.05$, **: $\mathrm{P}<0.01$ in comparison with control group. \#: $\mathrm{P}<0.05$ compared to the $\mathrm{CPZ}$ group.

\subsection{Effects on the time spent in open arms}

Compared to the control group, rats in the WIN group showed a significant decrease in the time spent on the open arms $(\mathrm{P}<0.01)$ whereas those in the $\mathrm{CPZ}(\mathrm{P}<0.05)$ and $\mathrm{WIN}+\mathrm{CPZ}(\mathrm{P}<0.01)$ groups showed a significant increase. Further, compared to the rats in the $\mathrm{CPZ}$ group, those in the $\mathrm{WIN}+\mathrm{CPZ}$ group showed a significant increase in the time spent on the open arms $(\mathrm{P}<0.05)$ (Figure 3).

\subsection{Effects on the closed arms entry}

The number of entries on to the closed arms was not significantly different between WIN, CPZ, and WIN+CPZ groups compared to the control group (Figure 4).

\section{Discussion}

The results of the present study indicate that the CB1 agonist (WIN) and the TRPV1 antagonist (CPZ) show an anxiolytic profile in rats. Our findings demonstrated that

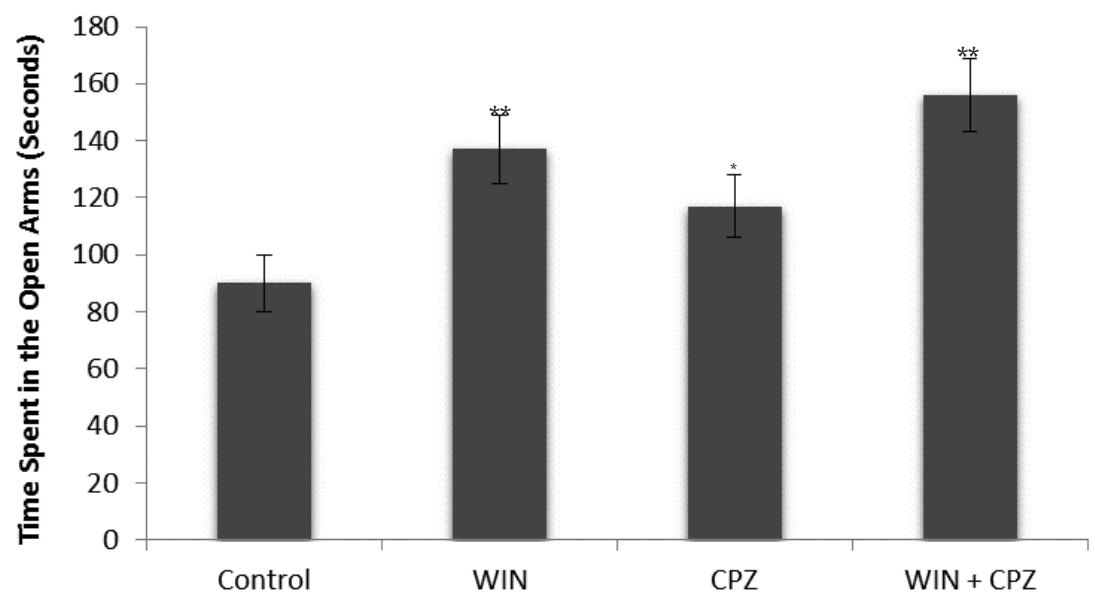

NEUR:SCIENCE

Figure 3. The effect of WIN212-2 (WIN), capsazepine (CPZ) and co-administration WIN+CPZ on the time spent in open arms during the 10 min test session ( $n=10$ in each group). Data are presented as mean $\pm S E M$. *: $P<0.05, * *: P<0.01$ in comparison with control group. \#: $\mathrm{P}<0.05$ compared to the $\mathrm{CPZ}$ group. 


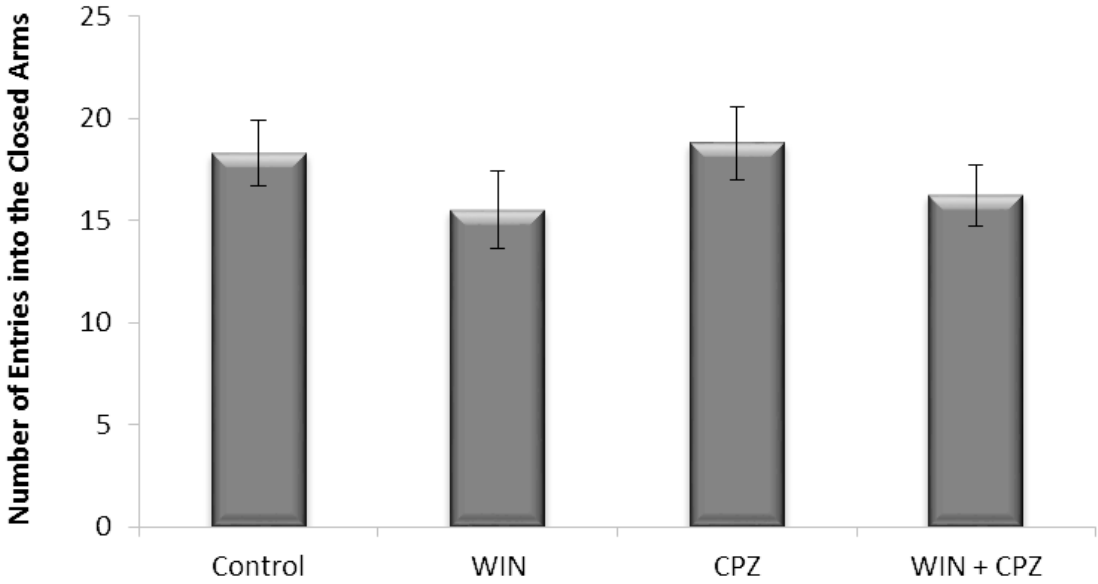

NEUR:SCIENCE

Figure 4. The effect of WIN212-2 (WIN) and capsazepine (CPZ) and co-administration WIN+CPZ on the number of closed arm entries during the $10 \mathrm{~min}$ test session $(\mathrm{n}=10)$ in each group). Data are presented as mean \pm SEM.

WIN and CPZ increased both assigned values of the time spent and number of passage onto the open arena of the maze. The consequences of WIN and CPZ administrations were not associated with the changes in natural motor activity of the animals since the total distance traveled by the rats and the number of passages on to the enclosed arena did not change. Increase in the time and ratio of the passage on to the open arena in the absence of any change in locomotor action can be regarded as a capable index for anxiolytic activity of the substances (Pellow, Chopin, File, \& Briley, 1985; Komaki et al., 2014b). In addition, co-administration of $\mathrm{CPZ}$ and WIN potentially increases the anxiolytic activity of these compounds in animals. Changes within the percentage of passage on to the open arena and time spent on these arena are regarded as reliable correlates of changes in the amount of anxiety in experimental models. Therefore, the EPM is advised as a validated and reliable device to reflect both anxiolyticand anxiogenic-like effects of various drugs (Pellow, et al., 1985; Pellow and File, 1986; Komaki, et al., 2014a; Komaki, et al., 2015b; Nemati, et al., 2015).

CB1 is a G-protein coupled receptor (Matsuda et al., 1990). Activation of CB1 receptors inhibits adenylate cyclase, resulting in decreases in intracellular calcium, and activates inwardly $\mathrm{K}^{+}$channels (Howlett et al., 2002), reduces neurotransmitter release (Vaughan, Connor, Bagley, \& Christie, 2000), and finally mediates anxiolytic-like effect (Rubino et al., 2007). Therefore, pharmacological substances that enhance endogenous cannabinoid signaling demonstrate anxiolytic-like actions (Bortolato et al., 2006; Kathuria et al., 2003).
Recent studies suggest the involvement of vanilloid receptors in the expression of anxiety-like behavior and the anxiolytic properties of cannabinoid agonists in mice and rats (Kasckow, Mulchahey, \& Thomas, 2004; Patel and Hillard, 2006; Roohbakhsh, Moghaddam, Massoudi, \& Zarrindast, 2007; Rubino et al., 2007). Blockade of TRPV1 resulted in anxiolytic-like behavior in TRPV1 receptor-deficient mice, (Marsch et al., 2007) and rats treated with a TRPV1 antagonist into the medial prefrontal cortex showed a similar effect (Aguiar et al., 2009). Moreover, blockade of TRPV1 channels induces anxiolytic-like effects (Aguiar et al., 2009; Fogaça et al. 2012). TRPV1 promotes cellular depolarization and increases neuronal firing rate (Xing and Li, 2007). TRPV1 is a calcium permeable ligand-gated cation channel that is expressed in various peripheral non-neuronal tissues and throughout the central nervous system (Montell et al., 2002). Activation of TRPV1 channels can stimulate calcium influx, facilitate the release of neurotransmitters (Musella et al., 2009, Starowicz et al., 2007) and may facilitate anxiogenic behavior (Marsch et al., 2007).

Different mechanisms are proposed to describe the interaction between the cannabinoid and vanilloid systems within the CNS. The attainable communication between TRPV1 and CB1 receptors on anxious status has been previously reported in hippocampus (Hakimizadeh and Oryan, 2012) or PAG (Campos and Guimaraes, 2009) regions. It has been suggested that lipid-based molecules such as anandamide-related compound may act on TRPV1 (di Marzo, et al., 1998; Beltramo and Piomelli, 1999), suggesting a possible interaction between the cannabinoid and vanilloid systems. Many studies 
have demonstrated that stimulation of CB1 and TRPV1 produces contrasting results in various research settings, including alteration in intracellular $\mathrm{Ca}^{2+}$ levels (Szallasi and Di Marzo, 2000) and glutamate liberate within the substantia nigra pars compacta (Marinelli, et al., 2003). It has been shown that HU210, as a synthetic cannabinoid receptor agonist, block capsaicin-induced entry of $\mathrm{Ca} 2+$. The repressive effects of this synthetic agonist, in total, are in line with the results of cannabinoid blockage of capsaicin-evoked effects (Oshita, et al., 2005).

CB1 and TRPV1 are detected in several brain areas (Fogaça et al., 2012; Mezey, 2000; Sagar et al., 2004; Tóth, Blumberg, \& Boczán, 2005). There are functional relationships between CB1 and TRPV1 receptors in neuronal cells (Hermann et al., 2003; Kim, et al., 2009; Sagar et al., 2004). Both CB1 and TRPV1 receptor properties are modified by a variety of factors, including desensitization/ internalization, heterodimerization, and phosphorylation (Hudson et al., 2001; Varga et al., 2006) and are involved in neural activity. Anandamide-associated construction might act on TRPV1(di Marzo, et al., 1998; Beltramo and Piomelli, 1999).

Stimulation of CB1 receptors might heighten activity by inhibiting TRPV1 receptors (Fogaca et al., 2012). Interaction between these two systems has also been reported. One mechanism for interactive effects with CB1 regarding TRPV1 is that arousal of TRPV1 increases intracellular $\mathrm{Ca}^{2+}$ levels, which can trigger the $\mathrm{Ca}^{2+}$-related $\mathrm{N}$-acyltransferase (NAT) (Reddy, et a., 1983). NAT regulates the rate-limiting stage in anandamide production and consequently, TRPV1 arousal may result in elevated anandamide production (Tóth et al., 2009). Anandamide could then trigger TRPV1 either directly or indirectly. Within the instance of direct arousal, anandamide may bind to and activate TRPV1. Direct arousal obviously happens once anandamide level is high. Low levels of anandamide may selectively trigger $\mathrm{CB} 1$ receptors (Tóth et al., 2009). Stimulation of CB1 receptors can result in desensitization, blockage, or potentiation of TRPV1 channels in neurons co-expressing $\mathrm{CB} 1$ receptors and TRPV1 channels (Hermann et al., 2003; Jeske et al., 2006; Evans, Scott, \& Ross, 2007; Kim, et al., 2009; Patwardhan et al., 2006). Co-administration of CPZ and WIN possibly modifies calcium influx, release of neurotransmitters, and potentiates the anxiolytic-like response in rats.

In conclusion, our experiments showed that acute neuropharmacological stimulation of CB1 receptors or blockade of TRPV1 receptors produced anxiolytic activity. The synergic effect of $\mathrm{CB} 1$ receptor activation and blockade of the TRPV1 receptor potentiated their anxiolytic response. Endogenous cannabinoid signaling is possibly enhanced by co-administration of WIN and CPZ. The results of changing cannabinoid system and regulating vanilloid transmission suggest that these two networks might contribute in some common signal transduction pathways. It has been revealed that the antagonists of vanilloid system regulate cannabinoid products, which can have anxiolytic-like effects. Further studies of the interaction between the cannabinoid and vanilloid systems are warranted.

\section{Acknowledgements}

The authors would like to express their gratitude to the staff of the Neurophysiology Research Center for their help in carrying out this project. This research was supported by a grant from the Hamadan University of Medical Sciences, Hamadan, Iran.

\section{Conflict of Interest}

The authors declare that there is no conflict of interests.

\section{References}

Aguiar, D. C., Terzian, A. L. B., Guimarães, F. S., \& Moreira, F. A. (2009). Anxiolytic-like effects induced by blockade of transient receptor potential vanilloid type 1 (TRPV1) channels in the medial prefrontal cortex of rats. Psychopharmacology, 205(2), 217-25. doi: 10.1007/s00213-009-1532-5

Almeida, V., Peres, F. F., Levin, R., Suiama, M. A., Calzavara, M B., Zuardi, A. W., et al. (2014). Effects of cannabinoid and vanilloid drugs on positive and negative-like symptoms on an animal model of schizophrenia: The SHR strain. Schizophrenia Research, 153(1-3), 150-9. doi: 10.1016/j.schres.2014.01.039

Baek, J. H., Zheng, Y., Darlington, C. L., \& Smith, P. F. (2009). The CB1 receptor agonist, WIN 55,212-2, dose-dependently disrupts object recognition memory in adult rats. Neuroscience Letters, 464(1), 71-3. doi: 10.1016/j.neulet.2009.08.008

Beltramo, M., \& Piomelli, D. (1999). Anandamide transport inhibition by the vanilloid agonist olvanil. European Journal of Pharmacology, 364(1), 75-8. doi: 10.1016/s0014-2999(98)00821-

Bergamaschi, M. M., Queiroz, R. H., Zuardi, A. W., \& Crippa, J. A. (2011). Safety and side effects of cannabidiol, a cannabis sativa constituent. Current Drug Safety, 6(4), 237-49. doi: $10.2174 / 157488611798280924$

Bortolato, M., Campolongo, P., Mangieri, R. A., Scattoni, M. L., Frau, R., Trezza, V., et al. (2006). Anxiolytic-like properties of the anandamide transport inhibitor AM404. Neuropsychopharmacology, 31(12), 2652-9. doi: 10.1038/sj.npp.1301061 
Burgos, E., Pascual, D., Martín, M. I., \& Goicoechea, C. (2010). Antinociceptive effect of the cannabinoid agonist, WIN $55,212-2$, in the orofacial and temporomandibular formalin tests. European Journal of Pain, 14(1), 40-8. doi: 10.1016/j.ejpain.2009.02.003

Cabranes, A., Venderova, K., de Lago, E., Fezza, F., Sánchez, A., Mestre, L., et al. (2005). Decreased endocannabinoid levels in the brain and beneficial effects of agents activating cannabinoid and/or vanilloid receptors in a rat model of multiple sclerosis. Neurobiology of Disease, 20(2), 207-17. doi: 10.1016/j. nbd.2005.03.002

Campos, A. C., \& Guimarães, F. S. (2009). Evidence for a potential role for TRPV1 receptors in the dorsolateral periaqueductal gray in the attenuation of the anxiolytic effects of cannabinoids. Progress in Neuro-Psychopharmacology and Biological Psychiatry, 33(8), 1517-21. doi: 10.1016/j.pnpbp.2009.08.017

Carvalho, A. F., \& Van Bockstaele, E. J. (2012). Cannabinoid modulation of noradrenergic circuits: Implications for psychiatric disorders. Progress in Neuro-Psychopharmacology and Biological Psychiatry, 38(1), 59-67. doi: 10.1016/j.pnpbp.2012.01.008

Caterina, M. J., Schumacher, M. A., Tominaga, M., Rosen, T. A., \& Levine, J. D. (1997). The capsaicin receptor: a heat-activated ion channel in the pain pathway. Nature, 389(6653), 816-24. doi: $10.1038 / 39807$

Chung J. M., Lee K. H., Yuichi, H., \& Willis, W. D. (1985). Effects of capsaicin applied to a peripheral nerve on the responses of primate spinothalamic tract cells. Brain Research, 329(1-2), 27-38. doi: 10.1016/0006-8993(85)90509-8

Crippa, J. A. S., Derenusson, G. N., Ferrari, T. B., Wichert-Ana, L., Duran, F. L., Martin-Santos, R., et al. (2011). Neural basis of anxiolytic effects of cannabidiol (CBD) in generalized social anxiety disorder: a preliminary report. Journal of Psychopharmacology, 25(1), 121-30. doi: 10.1177/0269881110379283

Cristino, L., de Petrocellis, L., Pryce, G., Baker, D., Guglielmotti, V., \& Di Marzo, V. (2006). Immunohistochemical localization of cannabinoid type 1 and vanilloid transient receptor potential vanilloid type 1 receptors in the mouse brain. Neuroscience, 139(4), 1405-15. doi: 10.1016/j.neuroscience.2006.02.074

Degroot, A. (2008). Role of Cannabinoid Receptors in Anxiety Disorders. Cannabinoids and the Brain, 559-72. doi: 10.1007/978-0-387-74349-3_24

Di Marzo, V., Bisogno, T., Melck, D., Ross, R., Brockie, H., Stevenson, L., et al. (1998). Interactions between synthetic vanilloids and the endogenous cannabinoid system. FEBS Letters, 436(3), 449-54. doi: 10.1016/s0014-5793(98)01175-2

Evans, R. M., Scott, R. H., \& Ross, R. A. (2009). Chronic exposure of sensory neurones to increased levels of nerve growth factor modulates CB1/TRPV1 receptor crosstalk. British Journal of Pharmacology, 152(3), 404-13. doi: 10.1038/sj.bjp.0707411

Fernandez-Lopez, D., Pradillo, J. M., Garcia-Yebenes, I., Martinez-Orgado, J. A., Moro, M. A., \& Lizasoain, I. (2010). The cannabinoid WIN55212-2 promotes neural repair after neonatal hypoxia-ischemia. Stroke, 41(12), 2956-64. doi: 10.1161/ strokeaha.110.599357

Fogaça, M. V., Aguiar, D. C., Moreira, F. A., \& Guimarães, F. S. (2012). The endocannabinoid and endovanilloid systems interact in the rat prelimbic medial prefrontal cortex to control anxiety-like behavior. Neuropharmacology, 63(2), 202-10. doi: 10.1016/j.neuropharm.2012.03.007
Ganji, A., Salehi, I., Sarihi, A., Shahidi, S., \& Komaki, A. (2016) Effects of Hypericum Scabrum extract on anxiety and oxidative stress biomarkers in rats fed a long-term high-fat diet. Metabolic Brain Disease, 32(2), 503-511. doi:10.1007/s11011 016-9940-9

Hakimizadeh, E., Oryan, S., Shamsizadeh, A., \& Roohbakhsh, A. (2012). Endocannabinoid system and TRPV1 receptors in the dorsal hippocampus of the rats modulate anxiety-like behaviors. Iranian Journal of Basic Medical Sciences, 15(3), 795-802.

Haller, J., Bakos, N., Szirmay, M., Ledent, C., \& Freund, T. F (2002). The effects of genetic and pharmacological blockade of the CB1 cannabinoid receptor on anxiety. European Journal of Neuroscience, 16(7), 1395-8. doi: 10.1046/j.14609568.2002.02192.x

Haller, J., Varga, B., Ledent, C., Barna, I., \& Freund, T. F. (2004a) Context-dependent effects of CB1 cannabinoid gene disruption on anxiety-like and social behaviour in mice. European Journal of Neuroscience, 19(7), 1906-12. doi: 10.1111/j.14609568.2004.03293.x

Haller, J., Varga, B., Ledent, C., \& Freund, T. F. (2004b). CB1 cannabinoid receptors mediate anxiolytic effects: convergent genetic and pharmacological evidence with CB1-specific agents. Behavioural Pharmacology, 15(4), 299-304. doi: 10.1097/01 fbp.0000135704.56422.40

Herkenham, M., Lynn, A. B., Little, M. D., Johnson, M. R. Melvin, L. S., de Costa, B. R., et al. (1990). Cannabinoid receptor localization in brain. Proceedings of the National Academy of Sciences, 87(5), 1932-6. doi: 10.1073/pnas.87.5.1932

Hermann, H., De Petrocellis, L., Bisogno, T., Schiano Moriello, A., Lutz, B., \& Di Marzo, V. (2003). Dual effect of cannabinoid CB 1 receptor stimulation on a vanilloid VR1 receptormediated response. Cellular and Molecular Life Sciences, 60(3), 607-16. doi: 10.1007/s000180300052

Hill, M. N., \& Gorzalka, B. B. (2004). Enhancement of anxietylike responsiveness to the cannabinoid CB1 receptor agonist HU-210 following chronic stress. European Journal of Pharmacology, 499(3), 291-5. doi: 10.1016/j.ejphar.2004.06.069

Ho, K. W., Ward, N. J., \& Calkins, D. J. (2012). TRPV1: A stress response protein in the central nervous system. American Journal of Neurodegenerative Disease, 1(1), 1-14.

Howlett, A. C., Barth, F., Bonner, T. I., Cabral, G., Casellas, P. Devane, W. A., Felder, C. C., et al. (2002). International Union of Pharmacology. XXVII. Classification of Cannabinoid Receptors. Pharmacological Reviews, 54(2), 161-202. doi: 10.1124/ pr.54.2.161

Hudson, L. J., Bevan, S., Wotherspoon, G., Gentry, C., Fox, A., \& Winter, J. (2001). VR1 protein expression increases in undamaged DRG neurons after partial nerve injury. European Journal of Neuroscience, 13(11), 2105-14. doi: 10.1046/j.0953 816x.2001.01591.x

Jeske, N. A., Patwardhan, A. M., Gamper, N., Price, T. J., Akopian, A. N., \& Hargreaves, K. M. (2006). Cannabinoid WIN 55,212-2 Regulates TRPV1 Phosphorylation in Sensory Neurons. Journal of Biological Chemistry, 281(43), 32879-90. doi: 10.1074/jbc.m603220200

Kasckow, J. W., Mulchahey, J. J., \& Geracioti, T. D. J. (2004) Effects of the vanilloid agonist olvanil and antagonist capsazepine on rat behaviors. Progress in Neuro-Psychopharma- 
cology and Biological Psychiatry, 28(2), 291-5. doi: 10.1016/j. pnpbp.2003.10.007

Kathuria, S., Gaetani, S., Fegley, D., Valiño, F., Duranti, A., Tontini, A., et al. (2002). Modulation of anxiety through blockade of anandamide hydrolysis. Nature Medicine, 9(1), 76-81. doi: $10.1038 / \mathrm{nm} 803$

Kaczocha, M., Glaser, S. T., Maher, T., Clavin, B., Hamilton, J., Rourke, J. O., et al. (2015). Fatty acid binding protein deletion suppresses inflammatory pain through endocannabinoid/nacylethanolamine-dependent mechanisms. Molecular Pain, 11, 52. doi: 10.1186/s12990-015-0056-8

Kim, S. R., Bok, E., Chung, Y. C., Chung, E. S., \& Jin, B. K. (2009). Interactions between $\mathrm{CB} 1$ receptors and TRPV1 channels mediated by 12-HPETE are cytotoxic to mesencephalic dopaminergic neurons. British Journal of Pharmacology, 155(2), 253-64. doi: 10.1038/bjp.2008.246

Komaki, A., Abdollahzadeh, F., Sarihi, A., Shahidi, S., \& Salehi, I. (2014a). Interaction between antagonist of cannabinoid receptor and antagonist of adrenergic receptor on anxiety in male rat. Basic and Clinical Neuroscience, 5(3), 218-24.

Komaki, A., Khaledi Nasab, Z., Shahidi, S., Sarihi, A., Salehi, I., \& Ghaderi, A. (2014b). Anxiolytic effects of acute injection of hydro-alcoholic extract of lettuce in the elevated plus-maze task in rats. Avicenna Journal of Neuro Psych Physiology, 1(1), 18695. doi: 10.17795/ajnpp-18695

Komaki, A., Hashemi-Firouzi, N., Shojaei, S., Souri, Z., Heidari, S., \& Shahidi, S. (2015a). Study the effect of endocannabinoid system on rat behavior in elevated plus-maze. Basic and Clinical Neuroscience, 6(3), 147-53.

Komaki, A., Rasouli, B., \& Shahidi, S. (2015b). Anxiolytic effect of borago officinalis (boraginaceae) extract in male rats. Avicenna Journal of Neuro Psych Physiology, 2(1), 27189. doi: 10.17795/ajnpp-27189

Lister, R. (1987). The use of a plus-maze to measure anxiety in the mouse. Psychopharmacology, 92(2), 180-5. doi: 10.1007/ bf00177912

Magierowski, M., Jasnos, K., Kwiecien, S., Drozdowicz, D., Surmiak, M., Strzalka, M., et al. (2015). Endogenous prostaglandins and afferent sensory nerves in gastroprotective effect of hydrogen sulfide against stress-induced gastric lesions. PLOS ONE, 10(3), 0118972. doi: 10.1371/journal.pone.0118972

Marco, E., \& Viveros, M. (2009). The critical role of the endocannabinoid system in emotional homeostasis: avoiding excess and deficiencies. Mini-Reviews in Medicinal Chemistry, 9(12), 1407-15. doi: 10.2174/138955709789957468

Marinelli, S., Di Marzo, V., Berretta, N., Matias, I., Maccarrone, M., Bernardi, G., et al. (2003). Presynaptic facilitation of glutamatergic synapses to dopaminergic neurons of the rat substantia nigra by endogenous stimulation of vanilloid receptors. Journal of Neuroscience, 23(8), 3136-44.

Marsch, R., Foeller, E., Rammes, G., Bunck, M., Kossl, M., Holsboer, F., et al. (2007). Reduced anxiety, conditioned fear, and hippocampal long-term potentiation in transient receptor potential vanilloid type 1 receptor-deficient mice. Journal of Neuroscience, 27(4), 832-9. doi: 10.1523/jneurosci.3303-06.2007

Mascarenhas, D. C., Gomes, K. S., \& Nunes-de-Souza, R. L. (2013). Anxiogenic-like effect induced by TRPV1 receptor activation within the dorsal periaqueductal gray matter in mice. Behavioural Brain Research, 250, 308-15. doi: 10.1016/j. bbr.2013.05.023

Matsuda, L. A., Lolait, S. J., Brownstein, M. J., Young, A. C., \& Bonner, T. I. (1990). Structure of a cannabinoid receptor and functional expression of the cloned cDNA. Nature, 346(6284), 561-4. doi: $10.1038 / 346561 \mathrm{a} 0$

Mezey, E. (2000). Distribution of mRNA for vanilloid receptor subtype 1 (VR1), and VR1-like immunoreactivity, in the central nervous system of the rat and human. Proceedings of the National Academy of Sciences, 97(7), 3655-60. doi: 10.1073/ pnas.060496197

Millan, M. J. (2003). The neurobiology and control of anxious states. Progress in Neurobiology, 70(2), 83-244. doi: 10.1016/ s0301-0082(03)00087-x

Montell, C., Birnbaumer, L., Flockerzi, V., Bindels, R. J., Bruford, E. A., Caterina, M. J., et al. (2002). A unified nomenclature for the superfamily of TRP cation channels. Molecular Cell, 9(2), 229-31. doi: 10.1016/s1097-2765(02)00448-3

Morales-Lázaro, S. L., Simon, S. A., \& Rosenbaum, T. (2013) The role of endogenous molecules in modulating pain through transient receptor potential vanilloid 1 (TRPV1). The Journal of Physiology, 591(13), 3109-21. doi: 10.1113/jphysiol.2013.251751

Moreira, F. A., Aguiar, D. C., \& Guimarães, F. S. (2007). Anxiolytic-like effect of cannabinoids injected into the rat dorsolateral periaqueductal gray. Neuropharmacology, 52(3), 958-65. doi: 10.1016/j.neuropharm.2006.10.013

Moreira, F. A., Kaiser, N., Monory, K., \& Lutz, B. (2008). Reduced anxiety-like behaviour induced by genetic and pharmacological inhibition of the endocannabinoid-degrading enzyme Fatty Acid Amide Hydrolase (FAAH) is mediated by CB1 receptors. Neuropharmacology, 54(1), 141-50. doi: 10.1016/j.neuropharm.2007.07.005

Musella, A., De Chiara, V., Rossi, S., Prosperetti, C., Bernardi, G., Maccarrone, M., \& Centonze, D. (2009). TRPV1 channels facilitate glutamate transmission in the striatum. Molecular and Cellular Neuroscience, 40(1), 89-97. doi: 10.1016/j. mcn.2008.09.001

Navarro, M., Hernández, E., Muñoz, R. M., del Arco, I., Villanúa, M. A., Carrera, M. R. A., \& Rodríguez de Fonseca, F. (1997). Acute administration of the CB1 cannabinoid receptor antagonist SR 141716A induces anxiety-like responses in the rat. NeuroReport, 8(2), 491-6. doi: 10.1097/00001756199701200-00023

Nemati, Z., Komaki, A., Shahidi, S., \& Sarihi, A. (2015). Effect of a hydroalcoholic extract of Rosa Canina flowers on anxiety in rats. Neurophysiology, 47(2), 133-7. doi: 10.1007/s11062-0159509-y

Nguyen, T. L., Nam, Y. S., Lee, S. Y., Kim, H. C., \& Jang, C. G. (2010). Effects of capsazepine, a transient receptor potential vanilloid type 1 antagonist, on morphine-induced antinociception, tolerance, and dependence in mice. British Journal of Anaesthesia, 105(5), 668-74. doi: 10.1093/bja/aeq212

Oshita, K., Inoue, A., Tang, H. B., Nakata, Y., Kawamoto, M. \& Yuge, O. (2005). CB1 Cannabinoid Receptor Stimulation Modulates Transient Receptor Potential Vanilloid Receptor 1 Activities in Calcium Influx and Substance P Release in Cultured Rat Dorsal Root Ganglion Cells. Journal of Pharmacological Sciences, 97(3), 377-85. doi: 10.1254/jphs.fp0040872 
Patel, S. \& Hillard C. J. (2006). Pharmacological evaluation of cannabinoid receptor ligands in a mouse model of anxiety: further evidence for an anxiolytic role for endogenous cannabinoid signalling. Journal of Pharmacology and Experimental Therapeutics, 318(1), 304-11. doi: 10.1124/jpet.106.101287

Patwardhan, A. M., Jeske, N. A., Price, T. J., Gamper, N., Akopian, A. N., \& Hargreaves, K. M. (2006). The cannabinoid WIN 55,212-2 inhibits Transient Receptor Potential Vanilloid 1 (TRPV1) and evokes peripheral antihyperalgesia via calcineurin. Proceedings of the National Academy of Sciences, 103(30), 11393-8. doi: $10.1073 /$ pnas.0603861103

Pellow, S., Chopin, P., File, S. E., \& Briley, M. (1985). Validation of open: closed arm entries in an elevated plus-maze as a measure of anxiety in the rat. Journal of Neuroscience Methods, 14(3), 149-67. doi: 10.1016/0165-0270(85)90031-7

Pellow, S., \& File, S. E. (1986). Anxiolytic and anxiogenic drug effects on exploratory activity in an elevated plus-maze: A novel test of anxiety in the rat. Pharmacology Biochemistry and Behavior, 24(3), 525-9. doi: 10.1016/0091-3057(86)90552-6

Reddy, P. V., Natarajan, V., Schmid, P. C., \& Schmid, H. H. O. (1983). N-acylation of dog heart ethanolamine phospholipids by transacylase activity. Biochimica et Biophysica Acta (BBA) Lipids and Lipid Metabolism, 750(3), 472-80. doi: 10.1016/00052760(83)90187-x

Richter, A., \& Löscher, W. (1994). (+)-WIN 55,212-2, a novel cannabinoid receptor agonist, exerts antidystonic effects in mutant dystonic hamsters. European Journal of Pharmacology, 264(3), 371-7. doi: 10.1016/0014-2999(94)00490-0

Roberts, J. C., Davis, J. B., \& Benham, C. D. (2004). [3H]Resiniferatoxin autoradiography in the CNS of wild-type and TRPV1 null mice defines TRPV1 (VR-1) protein distribution. Brain Research, 995(2), 176-83. doi: 10.1016/j.brainres.2003.10.001

Roohbakhsh, A., Moghaddam, A. H., Massoudi, R., \& Zarrindast, M. R. (2007). Role of dorsal hippocampal cannabinoid receptors and nitric oxide in anxiety like behaviours in rats using The Elevated Plus-Maze Test. Clinical and Experimental Pharmacology and Physiology, 34(3), 223-9. doi: 10.1111/j.14401681.2007.04576.x

Rubino, T., Realini, N., Castiglioni, C., Guidali, C., Vigano, D., Marras, E., et al. (2007). Role in anxiety behavior of the endocannabinoid system in the prefrontal cortex. Cerebral Cortex, 18(6), 1292-301. doi: 10.1093/cercor/bhm161

Ruehle, S., Rey, A. A., Remmers, F., \& Lutz, B. (2012). The endocannabinoid system in anxiety, fear memory and habituation. Journal of Psychopharmacology, 26(1), 23-39. doi: $10.1177 / 0269881111408958$

Sagar, D. R., Smith, P. A., Millns, P. J., Smart, D., Kendall, D. A., \& Chapman, V. (2004). TRPV1 and CB1 receptor-mediated effects of the endovanilloid/endocannabinoid N-arachidonoyldopamine on primary afferent fibre and spinal cord neuronal responses in the rat. European Journal of Neuroscience, 20(1), 175-84. doi: 10.1111/j.1460-9568.2004.03481.x

Saito, V. M., Wotjak, C. T., \& Moreira, F. A. (2010). [Pharmacological exploitation of the endocannabinoid system: new perspectives for the treatment of depression and anxiety disorders? (Portuguese)]. Revista Brasileira de Psiquiatria, 32, 7-14. doi: 10.1590/s1516-44462010000500004

Sánchez, A. M., Sánchez, M. G., Malagarie-Cazenave, S., Olea, N., \& Díaz-Laviada, I. (2006). Induction of apoptosis in pros- tate tumor PC-3 cells and inhibition of xenograft prostate tumor growth by the vanilloid capsaicin. Apoptosis, 11(1), 89-99. doi: 10.1007/s10495-005-3275-z

Schneier, F. R. (2011). Pharmacotherapy of social anxiety disorder. Expert Opinion on Pharmacotherapy, 12(4), 615-25. doi: $10.1517 / 14656566.2011 .534983$

Shabani, M., Divsalar, K., \& Janahmadi, M. (2012). Destructive effects of prenatal WIN 55212-2 exposure on central nervous system of neonatal rats. Addiction and Health, 4(1-2), 9-19.

Starowicz, K., Maione, S., Cristino, L., Palazzo, E., Marabese, I., Rossi, F., et al. (2007). Tonic endovanilloid facilitation of glutamate release in brainstem descending antinociceptive pathways. Journal of Neuroscience, 27(50), 13739-49. doi: 10.1523/ jneurosci.3258-07.2007

Szallasi, A., \& Di Marzo, V. (2000). New perspectives on enigmatic vanilloid receptors. Trends in Neurosciences, 23(10), 491 7. doi: 10.1016/s0166-2236(00)01630-1

Thiemann, G., Watt, C. A., Ledent, C., Molleman, A., \& Hasenöhrl, R. U. (2009). Modulation of anxiety by acute blockade and genetic deletion of the CB1 cannabinoid receptor in mice together with biogenic amine changes in the forebrain. Behavioural Brain Research, 200(1), 60-7. doi: 10.1016/j. bbr.2008.12.035

Tóth, A., Blumberg, P. M., \& Boczán, J. (2009). Anandamide and the vanilloid receptor (TRPV1). Vitamins \& Hormones, 81,389419. doi: 10.1016/s0083-6729(09)81015-7

Tóth, A., Boczán, J., Kedei, N., Lizanecz, E., Bagi, Z., Papp, Z., et al. (2005). Expression and distribution of vanilloid receptor 1 (TRPV1) in the adult rat brain. Molecular Brain Research, 135(12), 162-168. doi: 10.1016/j.molbrainres.2004.12.003

Varga, A., Bölcskei, K., Szöke, É., Almási, R., Czéh, G., Szolcsányi, J., et al. (2006). Relative roles of protein kinase A and protein kinase $\mathrm{C}$ in modulation of transient receptor potential vanilloid type 1 receptor responsiveness in rat sensory neurons in vitro and peripheral nociceptors in vivo. Neuroscience, 140(2), 645-57. doi: 10.1016/j.neuroscience.2006.02.035

Vaughan, C. W., Connor, M., Bagley, E. E., \& Christie, M. J. (2000). Actions of cannabinoids on membrane properties and synaptic transmission in rat periaqueductal gray neurons in vitro. Molecular Pharmacology, 57(2), 288-95.

Viveros, M., Marco, E., \& File, S. (2005). Endocannabinoid system and stress and anxiety responses. Pharmacology Biochemistry and Behavior, 81(2), 331-42. doi: 10.1016/j.pbb.2005.01.029

Xing, J., \& Li, J. (2007). TRPV1 receptor mediates glutamatergic synaptic input to dorsolateral Periaqueductal Gray (dlPAG) Neurons. Journal of Neurophysiology, 97(1), 503-11. doi: 10.1152/jn.01023.2006 
